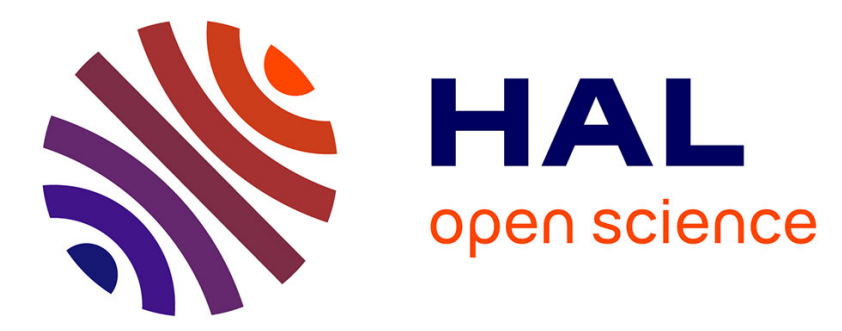

\title{
Plasma 11-oxotestosterone and gonadotrophin in relation to the arrest of spermiation in rainbow trout (Salmo gairdneri)
}

Alexis Fostier, Roland Billard, Bernard Breton

\section{To cite this version:}

Alexis Fostier, Roland Billard, Bernard Breton. Plasma 11-oxotestosterone and gonadotrophin in relation to the arrest of spermiation in rainbow trout (Salmo gairdneri). General and Comparative Endocrinology, 1984, 54 (3), pp.378-381. 10.1016/0016-6480(84)90150-3 . hal-02728568

\section{HAL Id: hal-02728568 \\ https://hal.inrae.fr/hal-02728568}

Submitted on 2 Jun 2020

HAL is a multi-disciplinary open access archive for the deposit and dissemination of scientific research documents, whether they are published or not. The documents may come from teaching and research institutions in France or abroad, or from public or private research centers.
L'archive ouverte pluridisciplinaire HAL, est destinée au dépôt et à la diffusion de documents scientifiques de niveau recherche, publiés ou non, émanant des établissements d'enseignement et de recherche français ou étrangers, des laboratoires publics ou privés.

\section{다(1)(2)}

Distributed under a Creative Commons Attribution - ShareAlikel 4.0 International 


\title{
Plasma 11-Oxotestosterone and Gonadotrophin in Relation to the Arrest of Spermiation in Rainbow Trout (Salmo gairdneri)
}

\author{
A. FostiER, ${ }^{*}$ R. Billard,, . AND B. BREton* \\ ${ }^{*}$ Laboratoire de Physiologie des Poissons Campus de Beaulieu, 35042 Rennes Cedex, France and $\dagger$ CNRZ, \\ 78350 Jouy-en-josas, France
}

Accepted June 28, 1983

\begin{abstract}
Plasma gonadotrophin (GTH) and 11-oxotestosterone levels have been studied in relation to sperm production during the last weeks of the spermiation period. The level of 11oxotestosterone decreased in parallel to sperm production (coefficient of correlation: $\rho=$ $0.59 ; P<0.01)$ and reached its lowest valucs $(\bar{X} \pm \mathrm{SE}=0.33 \pm 0.19 \mathrm{ng} / \mathrm{ml} ; n=11)$ when spermiation was over. No significant variations were found in GTH levels; however, there was a slight positive correlation between sperm production and GtH levels $(\rho=0.39 ; P<$ 0.05).
\end{abstract}

The endocrine control of spermiation in salmonids is still not clearly understood (Billard et al., 1982). High levels of glycoprotein gonadotrophin have been reported to occur during the spawning season (Crim et al., 1973, 1975; Crim and Evans, 1978; Billard et al., 1978; Whitehead et al., 1979; Stuart-Kregor et al., 1981). However, a slow decrease in plasma gonadotrophin was recorded in rainbow trout during the first 6 weeks of sperm release (Billard and Breton, 1977; Sanchez-Rodriguez et al., 1978; Fostier et al., 1982), after which gonadotrophin rose (Billard and Breton, 1977; SanchezRodriguez et al., 1978). No precise data are available concerning the end of spermiation. The analysis of monthly or bimonthly samples has shown a peak of plasma testosterone occurring before full spermiation, when 11-ketotestosterone and 11 $\beta$-hydroxytestosterone reach their maxima in brook trout (Sangalang and Freeman, 1974), rainbow trout (Scott et al., 1980), and brown trout (Kime and Manning, 1982). Idler et al. (1971) reported stable levels of testosterone and increasing levels of $11 \beta$ hydroxytestosterone and 11-oxotestosterone during spermiation in Atlantic salmon. However, in other studies (and thus probably in other strains), concomitant variations were reported between testosterone and 11-oxotestosterone in rainbow trout (Scott and Baynes, 1982) and Atlantic salmon (Hunt et al., 1982).

To appreciate better the relationships between the hormonal environment and the spermiation process, we thought it would be useful to closely follow endocrine changes when the physiological phenomenon, i.c., spermiation, appcared and disappeared. In a previous study (Fostier et al., 1982) we analyzed weekly relationships between plasma gonadotrophin and 11-oxotestosterone and sperm production at the onset of spermiation. This paper reports a comparable study performed during the last 6 weeks of sperm production.

\section{MATERIALS AND METHODS}

Animals. Twenty male rainbow trout (mean body weight $630 \mathrm{~g}$ ), handled for the first time for sperm collection (stripping), were individually tagged and kept in recycled fresh water under natural photoperiod and temperature $\left(6\right.$ to $13^{\circ}$ ) between January and March. During the experiment, seven fish died.

Sampling. Blood was sampled once a week and sperm every 2 weeks, as described previously by Fostier et al. (1982). Changes in the spermatozoa concentration were estimated by measuring the optical den- 
sity, at a wavelength of $410 \mathrm{~nm}$, of sperm diluted in a solution of $\mathrm{NaCl}(8 \%)$, knowing that the optical densities are linearly related to the spermatozoa concentration (Billard et al. 1971). Two males were still producing sperm at the end of the experimental period; thus only the other 11 fish were used for data analysis.

Hormone measurement. Plasma gonadotrophin (tGTH) and 11-oxotestosterone (11-oxoT) were measured using the radioimmunoassay already described by Fostier et al. (1982). Intrassay variability was CV $=28 \%(\bar{X}=2.7 \mathrm{ng} / \mathrm{ml} ; n=7)$ for GTH and $\mathrm{CV}=$ $9.3 \%(\bar{X}=26.7 \mathrm{ng} / \mathrm{ml} ; n=14)$ for 11 -oxoT.

Statistical analysis. Groups of samples taken on different dates were compared using variance analysis. The coefficients of correlation or Spearman rank correlations were calculated (Snedecor and Cochran, 1971).

\section{RESULTS AND DISCUSSION}

The 11 trout studied stopped spermiating between $8 / 2$ and $22 / 2$. The volume of collected sperm decreased continuously from 4 weeks before the end of spermiation (Fig. $1 \mathrm{~h})$. The gonadosomatic index measured at the end of the experiment $(\bar{X} \pm \mathrm{SD}=1.0$ $\pm 0.5 \%$ ) was similar to that of spent males (Billard et al., 1971). No difference in spermatozoa concentrations, estimated by the optical density measurements, was detected between fish or between dates of sampling (variance analysis). The general mean estimated at $4.1 \pm 1.3 \times 10^{9}$ spermatozoa/ml was low, as already observed for sperm collected at the end of the spawning season (Billard, 1974). Because of the homogeneity between samples of the spermatozoa concentrations, the volume of sperm collected has been taken as an indicator of the spermatozoa production.

When the whole experimental population was taken into account, no significant variations were found between plasma GTH levels at the different sampling dates. However, the individual profiles of five fish fluctuated before the end of spermiation (three have been plotted in Figs. 1a-c); the other six fish showed more regular GTH levels (four have been plotted in Figs. 1d-g). These differences between the two groups as to plasma GTH pattern could not be re- lated to any particular characteristic of sperm production or to 11-oxoT levels.

Plasma 11-oxoT levels decreased significantly in parallel to the volume of collected sperm (Fig. 1h). When no more sperm could be stripped from the males, mean 11oxo $T$ concentration reached $0.33 \mathrm{ng} / \mathrm{ml}$ (individual values between 0 and $2.04 \mathrm{ng} / \mathrm{ml}$ ) and has to be compared to the $61 \mathrm{ng} / \mathrm{ml}$ recorded 6 weeks earlier (individual values between 30.8 and $91.8 \mathrm{ng} / \mathrm{ml}$ ).

Sperm volume was positively correlated with the 11-oxoT levels found at the date of sampling (coefficient of correlation = $+0.59 ; P<0.01)$ and slightly correlated with the GTH levels (CR $=+0.39 ; P<$ 0.05 ). No significant correlation was found between the 11-oxoT and GTH levels.

As when spermiation begins (Fostier et al., 1982), the plasma 11-oxoT levels were correlated with the quantities of sperm collected during the last weeks of sperm production. Furthermore, there was a clear temporal relationship between the disappearance of 11-oxoT from the plasma and the arrest of spermiation. Unfortunately, there are few experimental studies on salmonid spermiation using 11-oxoT. Weekly injections of that androgen $(5 \mathrm{mg} / \mathrm{fish})$ in sockeye salmon induced spermiation after a treatment of 2-3 weeks (Idler et al., 1961), but Silastic implants of it (capsule length $=4 \mathrm{~cm} ; \Phi=2 \mathrm{~mm}$ ) in 150-day old rainbow trout did not significantly stimulate sperm production (Billard et al., 1982). In the latter case, steroid release was low compared to the high levels of intratesticular 11-oxoT; this would be expected, considering the plasma levels. Besides, these experiments were carried out on nonhypophysectomized animals, although negative 11-oxoT feedback on GTH secretion was shown at the spermiation stage (Billard, 1978).

The high levels of 11-oxoT during spermiation could maintain GTH secretion at a low level. However, at the onset of spermiation the higher GTH levels might stim- 


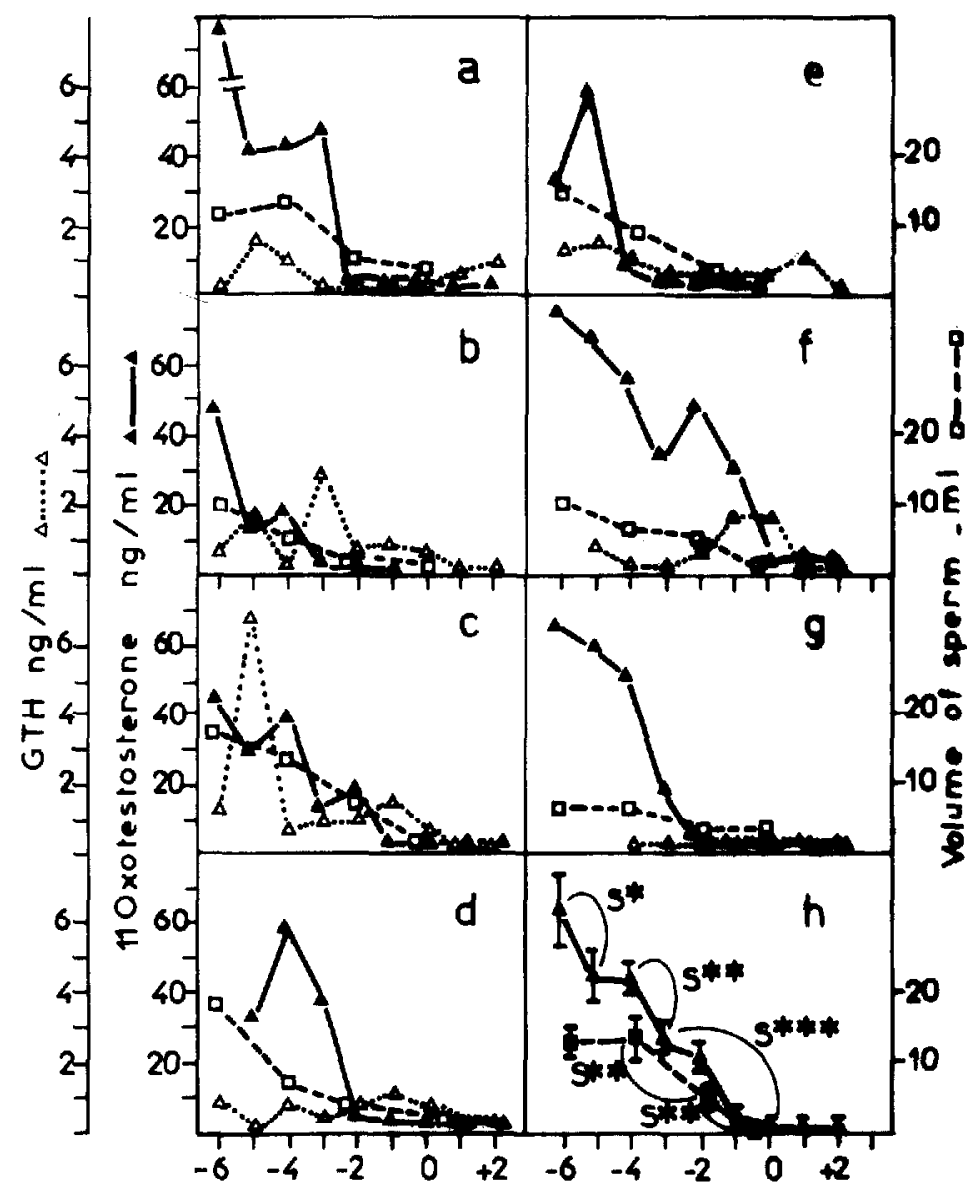

Fig. 1. Profile of sperm production plasma GTH $(\Delta)$, and plasma 11-oxoT $(\Delta)$ during the 6 weeks before and the 2 weeks after the end of spermiation ( 0 on abscissa) in male rainbow trout. Three individual profiles showing peaks of GTH $(a-c)$ and four others with more regular GTH patterns (dg) are presented. The last graph (h) shows the evolution of the means ( \pm SE) of all the experimental population (11 fish). $\mathrm{S}=$ levels significantly different, ${ }^{*} p<0.05,{ }^{* *} p<0.01,{ }^{* * *} p<0.001$.

ulate 11-oxoT secretion by the testis $\mathrm{Ng}$ and Idler, 1980; Magri et al., 1982; Lebail et al., 1983); this production would then be amplified by the gonadal-adrenal-hepatic positive feedback loop (Kime, 1978). The decrease of 11-oxoT secretion at the end of spermiation would not be related primarily to a drop in GTH levels but to a break in the positive feedback loop as, for instance, a qualitative and/or quantitative modification of the steroidogenic potentialities of the testis or of the other components of the loop. Nevertheless, we must be careful not to misinterpret the role of the pituitary since patterns of short-term blood GTH might show transitory peaks, as demonstrated in female (Zohar et al., 1981).

\section{ACKNOWLEDGMENTS}

We wish to thank P. Reinaud and O. Marcuzzi for their skillful assistance, and Ms. Alice Daifuku for helping edit the manuscript.

\section{REFERENCES}

Billard, R. (1974) La production spermatogénétique de la truite arc-en-ciel au cours du premier cycle reproducteur. Bull. Français Pisc. 253, 139-149.

Billard, R. (1978). Testicular feed back on the hypothalamo-pituitary axis in rainbow trout (Salmo 
gairdneri R.) Ann, Biol. Anim. Biochim. Biophys, 18, 813-818.

Billard, R., and Breton, B. (1977). Sensibilité à la température des différentes étapes de la reproduction chez la truite Arc-en-ciel. Cahier Labor. Montereau 5, 5-24.

Billard, R., Breton, B., and Jalabert, B. (1971). La production spermatogénétique chez la truite. Ann. Biol. Anim. Biochim. Biophys. 11, 190-212.

Billard, R., Breton, B., Fostier, A., Jalabert, B., and Weil, C. (1978). Endocrine control of the teleost reproductive cycle and its relations to external factor: Salmonid and cyprinid models. In "Comparative Endocrinology." (P. T. Gaillard and H. H. Boer, Eds.), pp. 37-48. Elsevier/NorthHolland, Amsterdam.

Billard, R., Fostier, A., Weil, C., and Breton, B. (1982). The endocrine control of spermatogenesis in teleost fish. Canad. J. Fish. Aquatic. Sci. 39, $65-79$.

Crim, L. W., and Evans, D. M. (1978). Seasonal levels of pituitary and plasma gonadotropin in male and female atlantic salmon parr. Canad. J. Zool. 56, 1550-1555.

Crim, L. W., Meyer, R. K., and Donaldson, F. M. (1973). Radioimmunoassay estimates of plasma gonadotropin levels in the spawning pink salmon. Gen. Comp. Endocrinol, 21, 69-76.

Crim, L. W., Watts, E. G., and Evans, D. M. (1975). The plasma gonadotropin profile during sexual maturation in a variety of salmonid fishes. Gen. Comp. Endocrinol. 27, 62-70.

Fostier, A., Billard, R., Breton, B., Legendre, M., and Marlot, S. (1982). Plasma 11-oxotestosterone and gonadotropin during the beginning of spermiation in rainbow trout (Salmo gairdneri). Gen. Comp. Endocrinol. 46, 428-434.

Hunt, S. M. V., Simpson, T. H., and Wright, R. S. (1982). Seasonal changes in the levels of 11-oxotestosterone and testosterone in the serum of male salmon, Salmo salar L., and their relationship to growth and maturation cycle. J. fish. Biol. 20, 105-119.

Idler, D. R., Bitners, I., and Schmidt, P. J. (1961). 11Ketotestosterone: An androgen for sockeye salmon. Canad. J. Biochim. Physiol. 39, 17371742.

Idler, D. R., Morne, D. A., and Sangalang, G. B. (1971). Identification and quantification of the major androgens in testicular and peripheral plasma of atlantic salmon (Salmo salar) during sexual maturation. Gen. Comp. Endocrinol. 16, 257-267.

Kime, D. E. (1978). The hepatic catabolism of cortisol in teleost fish adrenal origin of 11-oxotestosterone precursors. Gen. Comp. Endocrinol. 35, 322328.

Kime, D. E., and Manning, N. J. (1982). Seasonal patterns of free and conjugated androgens in the brown trout, Salmo trutta. Gen. Comp. Endocrinol. 48, 222-231.

Le Bail, P. Y., Fostier, A., and Marcuzzi, O. (1983). Limites et améliorations du sexage des salmonides par dosage de la 11-oxotestosterone circulante. Canad. J. Zool. 61, 457-460.

Magri, M. H., Billard, R., Reinaud, P., and Fostier, A. (1982). Induction of gametogenesis in the juvenile rainbow trout, Salmo gairdneri. Gen. Comp. Endocrinol. 46, 394 (Abst. 141).

$\mathrm{Ng}$ T. B., and Idler D. R. (1980). Gonadotropic regulation of androgen production in flounder and salmonids. Gen. Comp. Endocrinol. 42, 25-38.

Sanchez-Rodriguez, M., Escaffre, $\Lambda$. M., Marlot, S., and Reinaud, P. (1978). The spermiation period in the rainbow trout (Salmo gairdneri) plasma gonadotropin and androgen levels, sperm production and biochemical changes in the semimal fluid. Ann. Biol. Anim. Biochim. Biophys. 18, 943-948.

Sangalang, G. B., and Freeman, A. C. (1974). Effects of sublethal cadmium on maturation and testosterone and 11-ketotestosterone production in vivo in brook trout. Biol. Reprod. 11, 429-435.

Scott, A. P., Bye, V. I., Baynes, S. M., and Springate, J. R. C. (1980). Seasonal variations in plasma concentrations of 11-ketotestosterone and testosterone in male rainbow trout, Salmo gairdneri Richardson. J. Fish. Biol. 17, 495-505.

Scott, A. P., and Baynes, S. M. (1982). Plasma levels of sex steroids in relation to ovulation and spermiation in rainbow trout (Salmo gairdneri). In "Proceedings of the International Symposium on Reproductive Physiology of Fish" (C. J. J. Richter and H. J. Th. Goos, Ed.), pp. 103-106. Pudoc, Wageningen.

Snedecor, G. W., and Cochran, W. G. (1971). "Méthodes statistiques." Acta editor, Paris.

Stuart-Kregor, P. A. C. Sumpter, J. P., and Dodd, J. M. (1981). The involvement of gonadotrophin and sex steroids in the control of reproduction in the parr and adults of atlantic salmon, Salmo salar L. J. Fish. Biol. 18, 59-72.

Whitehead, C., Bromage, N. R., Breton, B., and Matty, A. J. (1979). Effect of altered photoperiod on serum gonadotrophin and testosterone levels in male rainbow trout. $J$. Endocrinol. 81, 139140.

Zohar, Y., Breton, B., and Billard, R. (1981). Shortterm profiles of plasma gonadotropin levels in the female rainbow trout throughout the reproductive cycle. Gen. Comp. Endocrinol. 46, 396 (Abst. 146). 